\title{
RESEARCH NOTE \\ Accumulation of macronutrients in cv. 'Astrus' cabbage as influenced by nitrogen dose and plant population
}

\author{
Arthur B. Cecílio Filho, ${ }^{1}$ Rodrigo L. Cavarianni, and Rodrigo H. D. Nowaki \\ Universidade Estadual Paulista, Plant Production Departament, Via de acesso Prof. Paulo Donato \\ Castellane, s/n CEP: 14884-900, Jaboticabal city. São Paulo, Brazil.
}

\begin{abstract}
A.B. Cecílio Filho, R.L. Cavarianni, and R.H.D. Nowaki. 2016. Accumulation of macronutrients in cv. 'Astrus' cabbage as influenced by nitrogen dose and plant population. Cien. Inv. Agr. 43(2):305-315 The influence of plant population ( 31,250 and 46,875 plants ha1) and nitrogen doses $\left(0,100,200\right.$, and $\left.300 \mathrm{~kg} \mathrm{ha}^{-1}\right)$ on the accumulation of macronutrients by cabbage plants was studied in Jaboticabal, Brazil, from February 18 to June 2, 2004. The experimental design was a randomized complete block in a $2 \times 4$ factorial scheme, with three replications. Differences in the amount of macronutrients accumulated by cabbage as function of $\mathrm{N}$ dose and plant population, were observed. The largest amounts of macronutrients were detected at the end of the plant cycle when the plant population was the lowest. The amounts of $\mathrm{N}, \mathrm{P}, \mathrm{K}$, and $\mathrm{S}$ were not significantly different when the $\mathrm{N}$ dose was increased from 100 to $300 \mathrm{~kg} \mathrm{ha}^{-1}$. The accumulated amounts of $\mathrm{Ca}$ and $\mathrm{Mg}$ were not significantly different when the $\mathrm{N}$ dose was increased from 200 to $300 \mathrm{~kg} \mathrm{ha}^{-1}$. The decreasing sequence of macronutrient extraction (Ca, N, K, Mg, P, and S) was not altered by the treatments. The period from 40 to 60 days after transplantation was responsible for half of the macronutrient accumulation by the cabbage plants.
\end{abstract}

Key words: Brassica oleracea var. capitata, spacing, uptake nutrients.

\section{Introduction}

Cabbage (Brassica oleraceae var. capitata) is the most important horticultural species of the Brassicaceae family in the world. However, in spite of its importance, fertilizer management still lacks information (Cecílio Filho et al., 2013). Among nutrients, nitrogen $(\mathrm{N})$ occupies a very important position not only because of its highly probable environmental impact (Westerveld et al., 2004)

Received April 28, 2015. Accepted May 29, 2016. Corresponding author: rutra@fcav.unesp.br but also because it is the second most accumulated nutrient in cabbage plants (Aquino et al., 2009) and has considerable impact on plant growth, productivity, and quality of the commercialized product (Westerveld et al., 2003a; Aquino et al., 2005a; Aquino et al., 2005b; Kolota and Chohura, 2015). Cabbage is very responsive to $\mathrm{N}$, with demands of up to $500 \mathrm{~kg} \mathrm{~N} \mathrm{ha}^{-1}$, according to the data reported by Westerveld et al. (2003a).

However, the efficiency of $\mathrm{N}$ fertilization is affected by factors such as soil, climate, genetic material, and cultural practices (Westerveld et 
al., 2003b; Oktem et al., 2010; Hawkesford et al., 2012). Consequently, the application of $\mathrm{N}$ should be studied under the conditions of the crop because the $\mathrm{N}$ nutritional status, as determined by the amount of $\mathrm{N}$ provided to the plants, interferes directly with the rate of absorption of the other nutrients and the dry matter accumulation of the plant (Aquino et al., 2009; Kolota and Chohura, 2015). Therefore, an important tool to know the demand levels and the moments of highest nutrient demand, as influenced by the $\mathrm{N}$ doses, is the progress of nutrient accumulation.

In addition to the $\mathrm{N}$ dose, the distance between plants is an important factor that determines the fertilization of cabbage plants. According to Sady et al. (2001), Schellenberg et al. (2009), and Kolota and Chohura (2015), alterations in plant spacing change the accumulation of dry matter by the plants. Aquino et al. (2009) studied the effects of $\mathrm{N}$ doses of $0,75,150,225$, and $300 \mathrm{~kg}$ $\mathrm{ha}^{-1}$ and plant distances of $80 \times 30,60 \times 30$, and $40 \times 30 \mathrm{~cm}$ on the content and exportation of macronutrients in a cabbage crop and verified that the highest doses of $\mathrm{N}$ caused increments in the $\mathrm{P}$ and $\mathrm{Mg}$ levels, whereas an increase in spacing resulted in higher levels of $\mathrm{P}, \mathrm{Ca}$, and $\mathrm{S}$, although with reduced dry matter accumulation. Kolota and Chohura (2015) observed that the dose of $150 \mathrm{~kg}$ $\mathrm{N} \mathrm{ha}^{-1}$ was a limiting factor for the increment of crop yield in plots with more than 44,000 plants $\mathrm{ha}^{-1}$. In the case of application, the dose of $300 \mathrm{~kg}$ $\mathrm{N} \mathrm{ha}^{-1}$ for plants grown in at 63,000 and 74000 plants ha ${ }^{-1}$ produced a significantly higher yield of heads than did the treatment with 44,000 plants.

Several studies have been reported that concern $\mathrm{N}$ doses for cabbage plants, including Khan et al. (2002), Aquino et al. (2005a, 2005b), Ekbladh et al. (2007), Haque et al. (2006), Machado et al. (2006); Aquino et al. (2009); Moreira et al. (2011). However, none of these investigations analyzed the accumulation of macronutrients by cabbage plants as influenced by the plant population and $\mathrm{N}$ doses.
Therefore, the objective of the present study was to evaluate the interaction of the plant population and $\mathrm{N}$ dose on the progress of absorption of macronutrients by cabbage plants of the 'Astrus' cultivar.

\section{Materials and methods}

The experiment was carried out from February 18 to June 2, 2004, in Jaboticabal, state of São Paulo, Brazil, at latitude $20^{\circ} 12^{\prime} 45.41^{\prime \prime}$ S, longitude $48^{\circ} 26^{\prime} 57.71^{\prime \prime} \mathrm{W}$ and a mean altitude of $528 \mathrm{~m}$ a.s.1.

The following conditions were used: population densities $\mathrm{D}_{1}, 31,250$ plants ha ${ }^{-1}$ with a plant spacing of $0.80 \times 0.40 \mathrm{~m}$ with two rows per plot, and $\mathrm{D}_{2}, 46,875$ plants ha ${ }^{-1}$ with a plant spacing of 0.40 $\times 0.40 \mathrm{~m}$ with three rows per plot triangularly arranged, and $\mathrm{N}$ doses of $\mathrm{N}_{0}=0, \mathrm{~N}_{1}=100, \mathrm{~N}_{2}$ $=200$, and $\mathrm{N}_{3}=300 \mathrm{~kg} \mathrm{ha}^{-1}$. The experimental design was a randomized complete block in a 2 $\times 4$ factorial scheme with three replications. The experimental plots were arranged in beds 1.1 $\mathrm{m}$ in width and $6.4 \mathrm{~m}$ in length with 32 and 48 plants for the smaller and larger plant densities, respectively.

The soil (Red Latosol) samples were taken at the $0-20 \mathrm{~cm}$ layer, and the results of their chemical analysis were the following: $\mathrm{pH}\left(\mathrm{CaCl}_{2}\right) 5.5$; organic matter $=27 \mathrm{~g} \mathrm{dm}^{-3} ; \mathrm{P}($ resin $)=56 \mathrm{mg} \mathrm{dm}^{-3} ; \mathrm{K}, \mathrm{Ca}$, $\mathrm{Mg}, \mathrm{H}+\mathrm{Al}$, and a cation exchange capacity of 3 , $38,12,28$, and $81 \mathrm{mmol}_{\mathrm{c}} \mathrm{dm}^{-3}$, respectively; $\mathrm{B}, \mathrm{Cu}$, $\mathrm{Fe}, \mathrm{Mn}$, and $\mathrm{Zn}$ of $0.17,6.9,17,32,9$, and 1,5 mg $\mathrm{dm}^{-3}$, respectively, and soil base saturation $(\mathrm{V})=$ $65 \%$. Based on the chemical analysis results and the proposal by Trani et al. (1997), the V was corrected, and soil fertilization with potassium and phosphorus was conducted. Thirty days before sowing, the soil acidity was corrected with calcined lime to raise the $\mathrm{V}$ to $80 \%$. At sowing, $400 \mathrm{~kg}$ ha $^{-1}$ of $\mathrm{P}_{2} \mathrm{O}_{5}$ (simple superphosphate) and $180 \mathrm{~kg}$ $\mathrm{ha}^{-1}$ of $\mathrm{K}_{2} \mathrm{O}$ (potassium chloride) were applied to the soil. An additional dose of $90 \mathrm{~kg} \mathrm{ha}^{-1}$ of $\mathrm{K}_{2} \mathrm{O}$ was divided in two and applied in side dressing to 
the plants 30 and 50 days after transplantation. $\mathrm{N}$ fertilizer (ammonium nitrate) was initially applied before sowing at the dose of $30 \mathrm{~kg} \mathrm{ha}^{-1}$ of $\mathrm{N}$ and was later side dressed to the plants at 15,30 , and 50 days after transplantation to reach the total amounts of 100, 200, and $300 \mathrm{~kg} \mathrm{ha}^{-1}$. Seeds of the 'Astrus' cabbage were sown on February 18, 2004 , in trays with a capacity of 128 plantlets, which were transplanted to beds on March 18, 2004, when they had four leaves. The cultural practices pertaining to the crop were conducted.

The amounts of macronutrients in the aboveground part of the plant (stem, internal and external leaves considered separately) were evaluated 20, 40, 60, and 75 days after transplantation. These determinations followed the methods found in Silva (2009). For each plant evaluation, Tukey's test was used to differentiate the treatments. A regression study was conducted using nonlinear models to represent the progress of nutrient accumulation. The equations with significant adjustment and highest determination coefficients were selected (test F).

\section{Results and discussion}

The $\mathrm{N}$ accumulation was influenced $(\mathrm{P} \leq 0.01)$ by the interaction between treatments and the sampling moment.

At 20 days after transplant (DAT), the $\mathrm{N}$ accumulation was larger in plants that were fertilized with $\mathrm{N}$, independent of the plant population. In contrast, at 40 DAT, the treatments were different not only as a consequence of plant fertilization but also because of the plant population. This tendency was confirmed to be significant at 60 and 75 DAT: the largest amounts of accumulated $\mathrm{N}$ were shown by plants that had been fertilized with $\mathrm{N}$ and those growing in the lowest plant population (Table 1). The largest amount of accumulated N (5.42 g plant $^{-1}$ ) was observed in the plant population of 31,250 plants ha ${ }^{-1}$ that was fertilized with 300 $\mathrm{kg} \mathrm{ha}^{-1}$ of $\mathrm{N}\left(\mathrm{D}_{1} \mathrm{~N}_{3}\right)$, which was not significantly different from the levels found for the $\mathrm{N}$ doses of 100 and $200 \mathrm{~kg} \mathrm{ha}^{-1}$ in the same plant population (Table 1). Half the amount of accumulated $\mathrm{N}$ in the plant dry matter was verified to occur at 45 and 51 DAT in the highest and lowest plant populations, respectively (Figure 1).

The largest amounts of $\mathrm{N}$ at the end of the plant cycle varied from $2.7\left(\mathrm{D}_{2} \mathrm{~N}_{0}\right)$ to $5.4\left(\mathrm{D}_{1} \mathrm{~N}_{2}\right.$ and $\left.\mathrm{D}_{1} \mathrm{~N}_{3}\right)$ g plant $^{-1}$ (Table 1). The accumulated amounts of $\mathrm{N}$ at the combinations of doses of $\mathrm{N}$ and plant population were between 7.67 and 2.45 g plant $^{-1}$, as reported by Peck (1981) and Oliveira et al. (2003), respectively. The plant population may be considered the most important factor that affects the amount of $\mathrm{N}$ in the plant. At the lower plant population, there was an increment in the $\mathrm{N}$ demand by the cabbage plants of the 'Astrus' variety (Table 1). In contrast, the accumulation of $\mathrm{N}$ by the crop in $\mathrm{kg} \mathrm{ha}^{-1}$ was higher in the highest population, with values of $127.9\left(\mathrm{D}_{2} \mathrm{~N}_{0}\right), 157.9$ $\left(\mathrm{D}_{2} \mathrm{~N}_{1}\right), 163.6\left(\mathrm{D}_{2} \mathrm{~N}_{2}\right), 172.9\left(\mathrm{D}_{2} \mathrm{~N}_{3}\right), 111.2\left(\mathrm{D}_{1} \mathrm{~N}_{0}\right)$, $144.1\left(\mathrm{D}_{1} \mathrm{~N}_{1}\right), 169.4\left(\mathrm{D}_{1} \mathrm{~N}_{2}\right)$, and $169.4\left(\mathrm{D}_{1} \mathrm{~N}_{3}\right)$.

At 20 DAT, the amount of $\mathrm{P}$ was larger in the plants that had been fertilized with $\mathrm{N}$ than in those that had not, regardless of plant population. At the end of the plant cycle (75 DAT), larger amounts of accumulated $\mathrm{P}$ were observed in plants that had been fertilized with $\mathrm{N}$ in the lowest plant population; on average, these values were $45.7 \%$ larger than those observed for the highest plant population (Table 1). The largest value of accumulated P (1.26 $\mathrm{g} \mathrm{plant}^{-1}$ ) was observed when the plant population was the lowest and the $\mathrm{N}$ dose was $200 \mathrm{~kg} \mathrm{ha}^{-1}$, which was not different from the values observed when the $\mathrm{N}$ dose was 100 and $300 \mathrm{~kg} \mathrm{ha}^{-1}$ at the

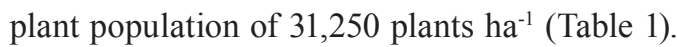
The curves for the accumulated amounts of $\mathrm{P}$ resulting from the combination of both factors (Figure 2) were similar to those of N (Figure 1) for the moments of highest demand and growth rate, thus confirming the data presented by Araújo and Machado (2006), which indicated a synergistic action between $\mathrm{N}$ and $\mathrm{P}$ on plant growth and yield. Therefore, the plants with the highest amounts of accumulated $\mathrm{N}$ also had the highest amounts of 
Table 1. Macronutrients accumulated by the aerial part of cabbage plants of the 'Astrus' variety as influenced by the treatments and sampling moment.

\begin{tabular}{|c|c|c|c|c|c|c|c|c|}
\hline $\begin{array}{l}\text { Cycle } \\
\left(\mathrm{DAT}^{3}\right)\end{array}$ & $\mathrm{D}_{1} \mathrm{~N}_{02}$ & $\mathrm{D}_{1} \mathrm{~N}_{1}$ & $\mathrm{D}_{1} \mathrm{~N}_{2}$ & $\mathrm{D}_{1} \mathrm{~N}_{3}$ & $\mathrm{D}_{2} \mathrm{~N}_{0}$ & $\mathrm{D}_{2} \mathrm{~N}_{1}$ & $\mathrm{D}_{2} \mathrm{~N}_{2}$ & $\mathrm{D}_{2} \mathrm{~N}_{3}$ \\
\hline \multicolumn{9}{|c|}{ Nitrogen $\left(g_{\text {plant }}^{-1}\right)$} \\
\hline 20 & $0.14 b^{1}$ & $0.36 \mathrm{a}$ & $0.41 \mathrm{a}$ & $0.38 \mathrm{a}$ & $0.15 \mathrm{~b}$ & $0.30 \mathrm{a}$ & $0.40 \mathrm{a}$ & $0.46 \mathrm{a}$ \\
\hline 40 & $0.73 \mathrm{c}$ & $1.51 \mathrm{abc}$ & $1.73 \mathrm{ab}$ & $1.84 \mathrm{a}$ & $0.95 \mathrm{bc}$ & $1.50 \mathrm{abc}$ & $1.57 \mathrm{ab}$ & $1.77 \mathrm{ab}$ \\
\hline 60 & $2.27 \mathrm{c}$ & $3.48 \mathrm{a}$ & $3.49 \mathrm{ab}$ & $4.11 \mathrm{a}$ & $2.25 \mathrm{c}$ & $2.29 \mathrm{c}$ & $2.60 \mathrm{c}$ & $2.68 \mathrm{bc}$ \\
\hline 75 & $3.56 \mathrm{bc}$ & $4.61 \mathrm{a}$ & $5.42 \mathrm{a}$ & $5.42 \mathrm{a}$ & $2.73 \mathrm{c}$ & $3.37 \mathrm{bc}$ & $3.49 \mathrm{bc}$ & $3.69 \mathrm{~b}$ \\
\hline \multicolumn{9}{|c|}{ Phosphorus (g plant ${ }^{-1}$ ) } \\
\hline 20 & $0.031 b^{1}$ & $0.072 \mathrm{a}$ & $0.076 \mathrm{a}$ & $0.074 \mathrm{a}$ & $0.033 \mathrm{~b}$ & $0.063 \mathrm{a}$ & $0.071 \mathrm{a}$ & $0.089 \mathrm{a}$ \\
\hline 40 & $0.149 \mathrm{~b}$ & $0.342 \mathrm{a}$ & $0.332 \mathrm{a}$ & $0.357 \mathrm{a}$ & $0.194 \mathrm{ab}$ & $0.305 \mathrm{ab}$ & $0.309 \mathrm{ab}$ & $0.347 \mathrm{ab}$ \\
\hline 60 & $0.477 \mathrm{~d}$ & $0.791 \mathrm{ab}$ & $0.747 \mathrm{bc}$ & $0.935 \mathrm{a}$ & $0.487 \mathrm{~d}$ & $0.518 \mathrm{~d}$ & $0.583 \mathrm{~cd}$ & $0.638 \mathrm{bcd}$ \\
\hline 75 & $0.825 \mathrm{~b}$ & $1.161 \mathrm{a}$ & $1.256 \mathrm{a}$ & $1.243 \mathrm{a}$ & $0.619 \mathrm{c}$ & $0.847 \mathrm{~b}$ & $0.790 \mathrm{~b}$ & $0.873 \mathrm{~b}$ \\
\hline \multicolumn{9}{|c|}{ Potassium (g plant $\left.{ }^{-1}\right)$} \\
\hline 20 & $0.09 \mathrm{~b}^{1}$ & $0.27 \mathrm{a}$ & $0.22 \mathrm{a}$ & $0.29 \mathrm{a}$ & $0.07 \mathrm{~b}$ & $0.15 \mathrm{a}$ & $0.18 \mathrm{a}$ & $0.19 \mathrm{a}$ \\
\hline 40 & $0.59 \mathrm{c}$ & $1.32 \mathrm{a}$ & $1.18 \mathrm{abc}$ & $1.39 \mathrm{a}$ & $0.66 \mathrm{bc}$ & $1.07 \mathrm{abc}$ & $1.03 \mathrm{abc}$ & $1.25 \mathrm{ab}$ \\
\hline 60 & $1.29 \mathrm{~cd}$ & $2.21 \mathrm{a}$ & $2.02 \mathrm{ab}$ & $2.37 \mathrm{a}$ & $1.14 \mathrm{~d}$ & $1.27 \mathrm{~cd}$ & $1.49 \mathrm{bcd}$ & $1.78 \mathrm{abc}$ \\
\hline 75 & $2.11 \mathrm{~b}$ & $3.21 \mathrm{a}$ & $3.51 \mathrm{a}$ & $3.63 \mathrm{a}$ & $1.79 \mathrm{~b}$ & $2.38 \mathrm{~b}$ & $2.33 \mathrm{~b}$ & $2.26 \mathrm{~b}$ \\
\hline \multicolumn{9}{|c|}{ Calcium (g plant $\left.{ }^{-1}\right)$} \\
\hline 20 & $0.16 b^{1}$ & $0.39 \mathrm{a}$ & $0.42 \mathrm{a}$ & $0.41 \mathrm{a}$ & $0.19 \mathrm{~b}$ & $0.41 \mathrm{a}$ & $0.48 \mathrm{a}$ & $0.53 \mathrm{a}$ \\
\hline 40 & $1.05 \mathrm{c}$ & $2.04 \mathrm{a}$ & $2.21 \mathrm{a}$ & $2.36 \mathrm{a}$ & $1.32 \mathrm{bc}$ & $1.98 \mathrm{bc}$ & $1.92 \mathrm{abc}$ & $2.10 \mathrm{a}$ \\
\hline 60 & $3.07 \mathrm{~cd}$ & $4.13 \mathrm{ab}$ & $3.85 \mathrm{bc}$ & $4.95 \mathrm{a}$ & $2.65 \mathrm{~d}$ & $2.92 \mathrm{~cd}$ & $3.24 \mathrm{bcd}$ & $3.51 \mathrm{bcd}$ \\
\hline 75 & $3.76 \mathrm{e}$ & $5.10 \mathrm{bc}$ & $6.44 \mathrm{a}$ & $6.05 \mathrm{a}$ & $3.63 \mathrm{e}$ & $3.96 \mathrm{de}$ & $4.35 \mathrm{cde}$ & $4.94 \mathrm{~cd}$ \\
\hline \multicolumn{9}{|c|}{ Magnesium (g plant $\left.{ }^{-1}\right)$} \\
\hline 20 & $0.03 b^{1}$ & $0.074 \mathrm{a}$ & $0.07 \mathrm{a}$ & $0.08 \mathrm{a}$ & $0.04 \mathrm{~b}$ & $0.07 \mathrm{a}$ & $0.08 \mathrm{a}$ & $0.10 \mathrm{a}$ \\
\hline 40 & $0.16 \mathrm{a}$ & $0.327 \mathrm{a}$ & $0.30 \mathrm{a}$ & $0.37 \mathrm{a}$ & $0.21 \mathrm{a}$ & $0.31 \mathrm{a}$ & $0.26 \mathrm{a}$ & $0.30 \mathrm{a}$ \\
\hline 60 & $0.43 \mathrm{c}$ & $0.743 \mathrm{ab}$ & $0.61 \mathrm{abc}$ & $0.80 \mathrm{a}$ & $0.54 \mathrm{bc}$ & $0.55 \mathrm{bc}$ & $0.56 \mathrm{bc}$ & $0.61 \mathrm{abc}$ \\
\hline 75 & $0.82 \mathrm{c}$ & $1.095 \mathrm{~b}$ & $1.61 \mathrm{a}$ & $1.55 \mathrm{a}$ & $0.83 \mathrm{c}$ & $0.83 \mathrm{c}$ & $0.97 \mathrm{bc}$ & $1.06 \mathrm{~b}$ \\
\hline \multicolumn{9}{|c|}{ Sulfur $\left(\right.$ g plant $\left.^{-1}\right)$} \\
\hline 20 & $0.03 \mathrm{a}^{1}$ & $0.06 \mathrm{a}$ & $0.06 \mathrm{a}$ & $0.06 \mathrm{a}$ & $0.03 \mathrm{a}$ & $0.05 \mathrm{a}$ & $0.06 \mathrm{a}$ & $0.03 \mathrm{a}$ \\
\hline 40 & $0.13 \mathrm{~b}$ & $0.26 \mathrm{ab}$ & $0.26 \mathrm{ab}$ & $0.27 \mathrm{a}$ & $0.14 \mathrm{ab}$ & $0.22 \mathrm{ab}$ & $0.22 \mathrm{ab}$ & $0.23 \mathrm{ab}$ \\
\hline 60 & $0.40 \mathrm{bc}$ & $0.58 \mathrm{a}$ & $0.52 \mathrm{ab}$ & $0.58 \mathrm{a}$ & $0.37 \mathrm{c}$ & $0.39 \mathrm{bc}$ & $0.43 \mathrm{bc}$ & $0.47 \mathrm{abc}$ \\
\hline 75 & $0.49 b c$ & $0.69 \mathrm{ab}$ & $0.77 \mathrm{a}$ & $0.77 \mathrm{a}$ & $0.40 \mathrm{c}$ & $0.53 \mathrm{bc}$ & $0.50 \mathrm{bc}$ & $0.54 \mathrm{~b}$ \\
\hline
\end{tabular}

${ }^{1}$ Means in the same line followed by the same letter are not significantly different $(\mathrm{P} \leq 0.05)$, according to Tukey's test. ${ }^{2} \mathrm{D}_{1}$ and $\mathrm{D}_{2}$ correspond to the populations of 31,250 and 46,875 plants ha ${ }^{-1}$ and $\mathrm{N}_{0}, \mathrm{~N}_{1}, \mathrm{~N}_{2}$, and $\mathrm{N}_{3}$ to the doses of $0,100,200$, and $300 \mathrm{~kg} \mathrm{ha}^{-1}$ of $\mathrm{N}$, respectively.

${ }^{3}$ Days after transplantation.

accumulated P (Figures 1 and 2). The high level of $\mathrm{P}$ in the soil (Raij et al., 1997), that is, $56 \mathrm{mg}$ $\mathrm{dm}^{-3}$, may have favored the synergism between those nutrients.

The average of the values of accumulated nutrients in the present study was $105 \%$ larger than that reported by Oliveira et al. (2003). As shown by the maximum amounts of $\mathrm{P}$ in the cabbage plants, the lowest plant population resulted in the highest value of accumulated $P$ (Table 1). However, the amount of $\mathrm{P}$ accumulated by the crop, in $\mathrm{kg} \mathrm{ha}^{-1}$, was the largest when the plant population was the largest and corresponded to $25.78\left(\mathrm{D}_{1} \mathrm{~N}_{0}\right), 36.28$ $\left(\mathrm{D}_{1} \mathrm{~N}_{1}\right), 39.25\left(\mathrm{D}_{1} \mathrm{~N}_{2}\right), 38.84\left(\mathrm{D}_{1} \mathrm{~N}_{3}\right), 29.01\left(\mathrm{D}_{2} \mathrm{~N}_{0}\right)$, $39.70\left(\mathrm{D}_{2} \mathrm{~N}_{1}\right), 37.03\left(\mathrm{D}_{2} \mathrm{~N}_{2}\right)$, and $40.92\left(\mathrm{D}_{2} \mathrm{~N}_{3}\right)$. 


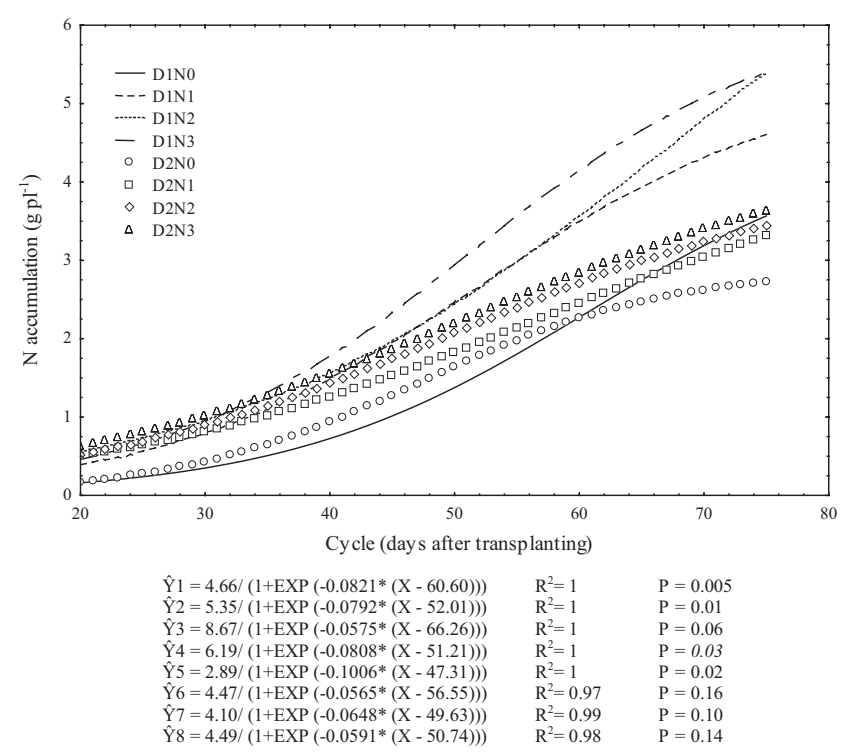

Figure 1. Nitrogen accumulation during the plant cycle in the dry matter of the aerial part of cabbage plants of the 'Astrus' variety, as influenced by the doses of $0\left(\mathrm{~N}_{0}\right), 100\left(\mathrm{~N}_{1}\right), 200\left(\mathrm{~N}_{2}\right)$, and $300\left(\mathrm{~N}_{3}\right) \mathrm{kg} \mathrm{ha}^{-1}$ of $\mathrm{N}$ and the populations of $31,250\left(\mathrm{D}_{1}\right)$ and 46,875 plants $\mathrm{ha}^{-1}\left(\mathrm{D}_{2}\right)$.

The amount of $\mathrm{K}$ accumulated by the cabbage plants was influenced $(\mathrm{P} \leq 0.01)$ by the treatments and sampling moments.

At 20 DAT, as observed for $\mathrm{N}$ and $\mathrm{P}$, the amounts of $\mathrm{K}$ in the plants growing in both plant populations were larger in plants that had been fertilized with $\mathrm{N}$ than in those that had not. At the end of the plant cycle, the highest (3.63 $\mathrm{g} \mathrm{plant}^{-1}$ ) amount of $\mathrm{K}$ was observed in plants growing in the plant population of 31,250 plants ha $\mathrm{a}^{-1}$ that received $300 \mathrm{~kg} \mathrm{ha}^{-1}$ of $\mathrm{N}$ $\left(\mathrm{D}_{1} \mathrm{~N}_{3}\right)$, which was not significantly different from the treatments with the application of $\mathrm{N}$ at the same plant population (Table 1). The $\mathrm{D}_{1} \mathrm{~N}_{3}$ combination permitted an amount of accumulated $\mathrm{K}$ that was $156 \%$ larger than that observed for the plants grown in the same plant population but without $\mathrm{N}$ fertilization and $114 \%$ larger than that observed for plants that had been fertilized with $\mathrm{N}$ but were grown in the highest plant population (Table 1).

Half of the K accumulated by the plants fertilized with $300 \mathrm{~kg} \mathrm{ha}^{-1}$ and at the lowest plant population was verified to take longer to occur, that is, at 55 DAT, whereas the earliest accumulation (39 DAT) was verified in the same dose but at the highest plant population (Figure 3). This earliness may be ascribed to the higher competition for resources between plants growing in higher plant populations.

The largest amounts of $\mathrm{K}$ in the plant were observed at the end of the plant cycle, and they increased as the amount of applied $\mathrm{N}$ fertilizer increased (Table 1). The amounts of $\mathrm{K}\left(\mathrm{kg} \mathrm{ha}^{-1}\right)$ were 65.9 $\left(\mathrm{D}_{1} \mathrm{~N}_{0}\right), 100.3\left(\mathrm{D}_{1} \mathrm{~N}_{1}\right), 108.9\left(\mathrm{D}_{1} \mathrm{~N}_{2}\right), 109.7\left(\mathrm{D}_{1} \mathrm{~N}_{3}\right)$, $83.9\left(\mathrm{D}_{2} \mathrm{~N}_{0}\right), 115.6\left(\mathrm{D}_{2} \mathrm{~N}_{1}\right), 109.2\left(\mathrm{D}_{2} \mathrm{~N}_{2}\right)$, and 105.9 $\left(\mathrm{D}_{2} \mathrm{~N}_{3}\right)$. In contrast to what was verified for $\mathrm{N}$ and $\mathrm{P}$, the accumulated amounts of $\mathrm{K}$ for each evaluated dose were very close between the plant populations. This is supposedly related to the roles played by $\mathrm{K}$ in photosynthesis, which is related to leaf area. Because plants growing in a plant population of 46,875 plants ha ${ }^{-1}$ undergo more severe intraspecific competition, they grow less; that is, they have smaller leaf area and therefore demand less K. Thus, even with 50\% more plants, the amounts of accumulated $\mathrm{K}$ at each dose of $\mathrm{N}$ were similar in both plant populations.

The treatments and sampling moment interacted significantly $(\mathrm{P} \leq 0.01)$ to determine the amount of accumulated $\mathrm{Ca}$ in the plant aboveground dry mass. 


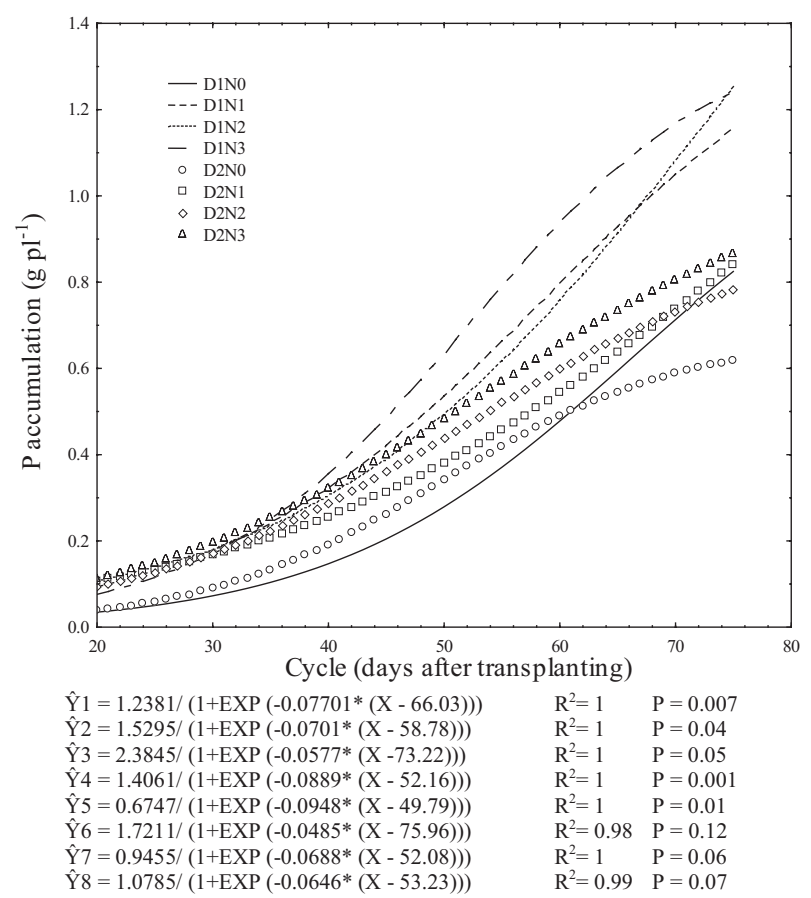

Figure 2. Phosphorus accumulation during the plant cycle in the dry matter of the aerial part of cabbage plants of the 'Astrus' variety, as influenced by the doses of $0\left(\mathrm{~N}_{0}\right), 100\left(\mathrm{~N}_{1}\right), 200\left(\mathrm{~N}_{2}\right)$, and $300\left(\mathrm{~N}_{3}\right) \mathrm{kg} \mathrm{ha}^{-1}$ of $\mathrm{N}$ and the populations of $31,250\left(\mathrm{D}_{1}\right)$ and 46,875 plants ha $^{-1}\left(\mathrm{D}_{2}\right)^{3}$.

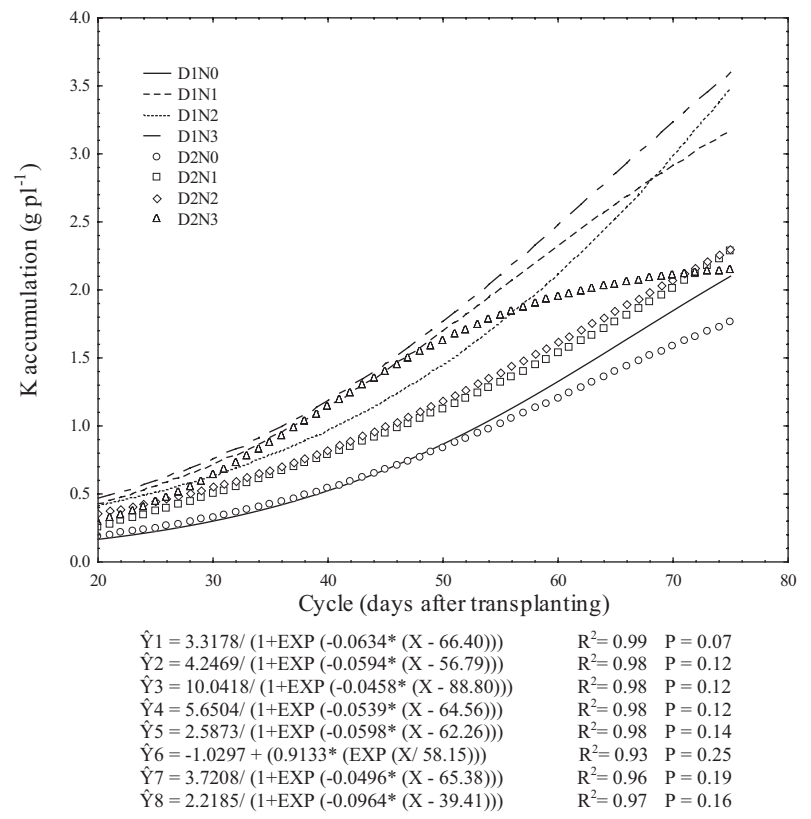

Figure 3. Potassium accumulation during the plant cycle in the dry matter of the aerial part of cabbage plants of the 'Astrus' variety, as influenced by the doses of $0\left(\mathrm{~N}_{0}\right), 100\left(\mathrm{~N}_{1}\right), 200\left(\mathrm{~N}_{2}\right)$, and $300\left(\mathrm{~N}_{3}\right) \mathrm{kg} \mathrm{ha}^{-1}$ of $\mathrm{N}$ and the populations of $31,250\left(D_{1}\right)$ and 46,875 plants ha ${ }^{-1}\left(D_{2}\right)$. 
At 20 DAT, in both plant populations, the amount of $\mathrm{Ca}$ in plants that were not fertilized with $\mathrm{N}$ was already lower than that found in plants that had been fertilized with N. During plant growth, the amounts of accumulated $\mathrm{Ca}$ in plants that had received 200 and $300 \mathrm{~kg} \mathrm{ha}^{-1}$ of $\mathrm{N}$ and were growing in the lower population were lower than those observed for the other treatments. This tendency was ratified 75 DAT, when the amounts of $\mathrm{Ca}$ accumulated by the plants were the highest (Table 1). Similar to the observed amounts of N, P, and K, the amounts of Ca in plants fertilized with $\mathrm{N}$ were not significantly different in the higher plant population (Table 1).

Half of the total amount of accumulated Ca was reached between 44 and 53 DAT, with mean values of 48 and 46 DAT in the plant populations of 31,250 and 46,875 plants ha ${ }^{-1}$, respectively (Figure 4). The amounts of $\mathrm{Ca}$, in $\mathrm{kg} \mathrm{ha}^{-1}$, that were accumulated by the plants, as determined by the treatments (Table 1), were $117.5\left(\mathrm{D}_{1} \mathrm{~N}_{0}\right), 159.37$ $\left(\mathrm{D}_{1} \mathrm{~N}_{1}\right), 201.25\left(\mathrm{D}_{1} \mathrm{~N}_{2}\right), 189.06\left(\mathrm{D}_{1} \mathrm{~N}_{3}\right), 170.15\left(\mathrm{D}_{2} \mathrm{~N}_{0}\right)$, $185.62\left(\mathrm{D}_{2} \mathrm{~N}_{1}\right), 203.90\left(\mathrm{D}_{2} \mathrm{~N}_{2}\right)$, and $231.56\left(\mathrm{D}_{2} \mathrm{~N}_{3}\right)$.

The treatments and the sampling moment interacted significantly $(\mathrm{P} \leq 0.01)$ to determine the amount of accumulated Mg in the plant aboveground dry mass.

At 20 DAT, independent of the plant population, the plants with the highest amounts of $\mathrm{Mg}$ were those that had been fertilized with N. Twenty days later, the treatments were no longer significantly different. At 75 DAT, however, in the lower plant population, the plants that had been fertilized with $\mathrm{N}$ showed $53 \%$ more $\mathrm{Mg}$ than did those in the higher plant population. The highest amount of $\mathrm{Mg}$ was brought about by the $\mathrm{N}$ dose of 200 $\mathrm{kg} \mathrm{ha}^{-1}$ in the smaller plant population, although it was not significantly different from the plants that had been fertilized with $300 \mathrm{~kg} \mathrm{ha}^{-1}$ of $\mathrm{N}$ in the same plant population. Similar to what had been observed for $\mathrm{K}$ and $\mathrm{Ca}$ and different from that observed for $\mathrm{N}$ and $\mathrm{P}$, the amounts of accumulated $\mathrm{Mg}$ were not significantly different in both plant populations when no $\mathrm{N}$ was applied (Table 1). The curves describing the accumulation of $\mathrm{Mg}$ show that the plants growing in the smaller plant population reached half the total of that nutrient at different moments according to the treatment, whereas for the $\mathrm{D}_{1} \mathrm{~N}_{1}$ treatment, that moment took place at 52 DAT, and for the $\mathrm{D}_{1} \mathrm{~N}_{2}$ treatment, that moment was verified only at 64 DAT. In contrast, when the plant population was of 46,875 plants ha $^{-1}$, that moment was approximately the same for all treatments, i.e., between 54 and 56 DAT (Figure 5).

The amounts of accumulated $\mathrm{Mg}$, in $\mathrm{kg} \mathrm{ha}^{-1}$, were as follows: $25.7\left(\mathrm{D}_{1} \mathrm{~N}_{0}\right), 34.2\left(\mathrm{D}_{1} \mathrm{~N}_{1}\right), 50.4$ $\left(\mathrm{D}_{1} \mathrm{~N}_{2}\right), 48.3\left(\mathrm{D}_{1} \mathrm{~N}_{3}\right), 38.6\left(\mathrm{D}_{2} \mathrm{~N}_{0}\right), 38.67\left(\mathrm{D}_{2} \mathrm{~N}_{1}\right)$, $45.5\left(\mathrm{D}_{2} \mathrm{~N}_{2}\right)$, and $49.5\left(\mathrm{D}_{2} \mathrm{~N}_{3}\right)$.

The treatments and the sampling moment interacted significantly $(\mathrm{P} \leq 0.01)$ to determine the amount of accumulated $\mathrm{S}$ in the plant aboveground dry mass.

At 20 DAT, although the amounts of nutrients found in the plants fertilized with N were $108 \%$ higher than those found in the plants that were not fertilized, the treatments were not significantly different. At 40 DAT, only treatments $\mathrm{D}_{1} \mathrm{~N}_{0}$ and $\mathrm{D}_{1} \mathrm{~N}_{3}$ were significantly different. At 60 DAT, the plants growing in the smaller plant population that had received $300 \mathrm{~kg} \mathrm{ha}^{-1}$ of $\mathrm{N}\left(\mathrm{D}_{1} \mathrm{~N}_{3}\right)$ kept showing the highest amount of accumulated $\mathrm{S}$, although it was not different from $\mathrm{D}_{1} \mathrm{~N}_{1}, \mathrm{D}_{1} \mathrm{~N}_{2}$, and $\mathrm{D}_{2} \mathrm{~N}_{3}$. At the end of the crop cycle, plants growing in the lower plant population that received $\mathrm{N}$ doses of 200 and $300 \mathrm{~kg}$ $\mathrm{ha}^{-1}$ had accumulated the same amount of S, which was not different from that accumulated by plants that had received a $\mathrm{N}$ dose of $100 \mathrm{~kg} \mathrm{ha}^{-1}$ (Table 1).

In the lower plant population, the treatments by which the plants received $\mathrm{N}$ were not significantly different, such as those observed for N, P, and K. In the larger plant population, only the dose of 300 $\mathrm{kg} \mathrm{ha}^{-1}$ of $\mathrm{N}$ resulted in an amount of accumulated $\mathrm{S}$ that was significantly superior to that shown by the plants that did not receive $\mathrm{N}$ (Table 1).

According to Figure 6, half of the total accumulated S was reached approximately 48 and 45 DAT in the low and high plant populations, respectively, 


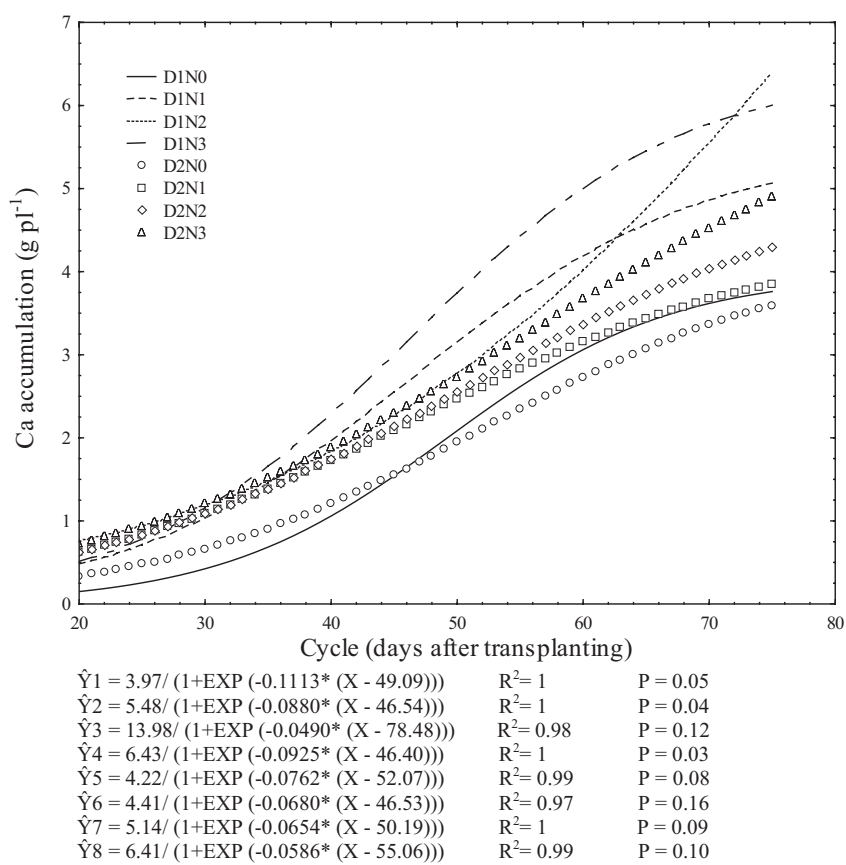

Figure 4. Calcium accumulation during the plant cycle in the dry matter of the aerial part of cabbage plants of the 'Astrus' variety, as influenced by the doses of $0\left(\mathrm{~N}_{0}\right), 100\left(\mathrm{~N}_{1}\right), 200\left(\mathrm{~N}_{2}\right)$, and $300\left(\mathrm{~N}_{3}\right) \mathrm{kg} \mathrm{ha}^{-1}$ of $\mathrm{N}$ and the populations of $31,250\left(\mathrm{D}_{1}\right)$ and 46,875 plants ha ${ }^{-1}\left(\mathrm{D}_{2}\right)$.

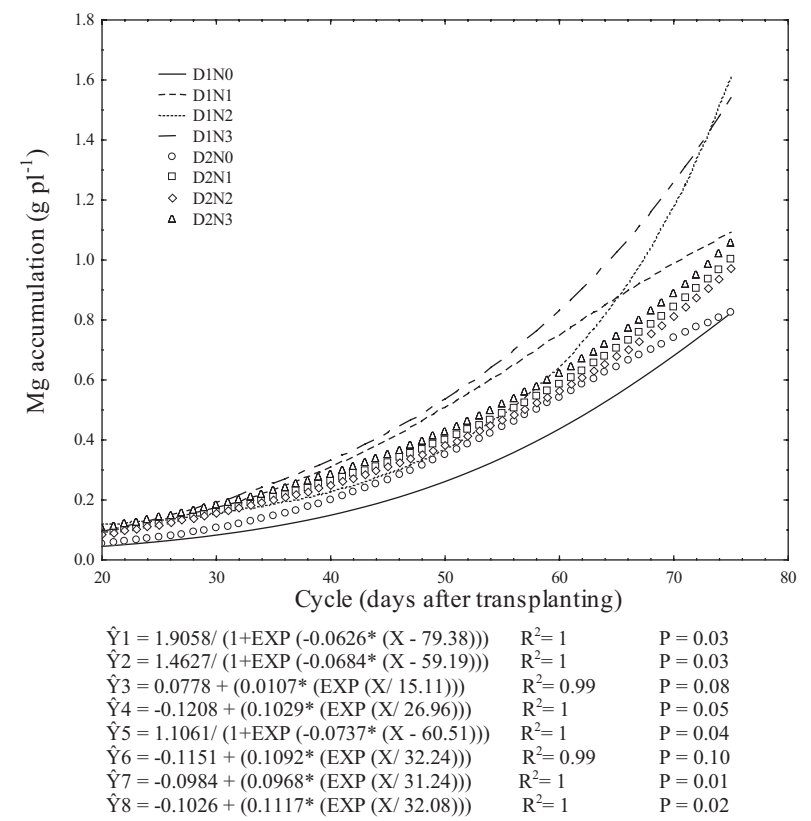

Figure 5. Magnesium accumulation during the plant cycle in the dry matter of the aerial part of cabbage plants of the 'Astrus' variety, as influenced by the doses of $0\left(\mathrm{~N}_{0}\right), 100\left(\mathrm{~N}_{1}\right), 200\left(\mathrm{~N}_{2}\right)$, and $300\left(\mathrm{~N}_{3}\right) \mathrm{kg} \mathrm{ha}^{-1}$ of $\mathrm{N}$ and the populations of $31,250\left(D_{1}\right)$ and 46,875 plants ha ${ }^{-1}\left(D_{2}\right)$. 
with an amplitude of 44 to 51 DAT. The amounts of accumulated $\mathrm{S}$ were larger in the plants growing in the higher plant population. The amounts, in $\mathrm{kg} \mathrm{ha}^{-1}$, were $15.34\left(\mathrm{D}_{1} \mathrm{~N}_{0}\right), 21.50\left(\mathrm{D}_{1} \mathrm{~N}_{1}\right), 23.93$ $\left(\mathrm{D}_{1} \mathrm{~N}_{2}\right), 23.93\left(\mathrm{D}_{1} \mathrm{~N}_{3}\right), 18.93\left(\mathrm{D}_{2} \mathrm{~N}_{0}\right), 24.79\left(\mathrm{D}_{2} \mathrm{~N}_{1}\right)$, $23.43\left(\mathrm{D}_{2} \mathrm{~N}_{2}\right)$, and $25.5\left(\mathrm{D}_{2} \mathrm{~N}_{3}\right)$.

The decreasing order with which the macronutrients accumulated in the plant dry matter was not affected by the $\mathrm{N}$ dose and plant population. However, the proportion among them was modified, as indicated in Table 2. The higher accumulation of $\mathrm{Ca}$ in comparison with $\mathrm{N}$ probably results from luxury consumption, which was favored by the high concentration of $\mathrm{Ca}$ in the soil of the experiment ( $38 \mathrm{mmol}_{\mathrm{c}} \mathrm{dm}^{-3}$, a very high concentration, according to Raij et al. (1997)). The lime that was applied to increase the base saturation to $80 \%$ (as recommended by Trani et al. (1997)) probably also contributed to that luxury consumption. The observed order differed from that (N, K, S, Ca, P, and Mg) noted by Furlani et al. (1978).

In conclusion, 'Astrus' cabbage plants that receive between 0 and $300 \mathrm{~kg} \mathrm{ha}^{-1}$ doses of $\mathrm{N}$ and have
Table 2. Decreasing order with which macronutrients accumulated in 'Astrus' cabbage plants as influenced by the treatments.

\begin{tabular}{lc}
\hline Treatments & Accumulation order \\
\hline $\mathrm{D}_{1} \mathrm{~N}_{0}{ }^{1}$ & $\mathrm{Ca} \approx \mathrm{N}>\mathrm{K}>\mathrm{Mg}=\mathrm{P}>\mathrm{S}^{2}$ \\
$\mathrm{D}_{1} \mathrm{~N}_{1}$ & $\mathrm{Ca} \approx \mathrm{N}>\mathrm{K}>\mathrm{Mg} \approx \mathrm{P}>\mathrm{S}$ \\
$\mathrm{D}_{1} \mathrm{~N}_{2}$ & $\mathrm{Ca}>\mathrm{N}>\mathrm{K}>\mathrm{Mg}>\mathrm{P}>\mathrm{S}$ \\
$\mathrm{D}_{1} \mathrm{~N}_{3}$ & $\mathrm{Ca}>\mathrm{N}>\mathrm{K}>\mathrm{Mg}>\mathrm{P}>\mathrm{S}$ \\
$\mathrm{D}_{2} \mathrm{~N}_{0}$ & $\mathrm{Ca}>\mathrm{N}>\mathrm{K}>\mathrm{Mg}>\mathrm{P}>\mathrm{S}$ \\
$\mathrm{D}_{2} \mathrm{~N}_{1}$ & $\mathrm{Ca}>\mathrm{N}>\mathrm{K}>\mathrm{Mg}=\mathrm{P}>\mathrm{S}$ \\
$\mathrm{D}_{2} \mathrm{~N}_{2}$ & $\mathrm{Ca}>\mathrm{N}>\mathrm{K}>\mathrm{Mg}>\mathrm{P}>\mathrm{S}$ \\
$\mathrm{D}_{2} \mathrm{~N}_{3}$ & $\mathrm{Ca}>\mathrm{N}>\mathrm{K}>\mathrm{Mg}>\mathrm{P}>\mathrm{S}$ \\
\hline
\end{tabular}

${ }^{1} \mathrm{D}_{1}$ and $\mathrm{D}_{2}$ correspond to the populations of 31,250 and 46,875 plants ha ${ }^{-1}$ and $\mathrm{N}_{0}, \mathrm{~N}_{1}, \mathrm{~N}_{2}$, and $\mathrm{N}_{3}$ to doses of 0,100 , 200 , and $300 \mathrm{~kg} \mathrm{ha}^{-1}$ of $\mathrm{N}$, respectively.

${ }^{2}>, \approx$, and $=$ correspond to accumulations in proportions larger than $10 \%$, up to $10 \%$, and up to $1 \%$ of the nutrient in comparison, respectively.

populations of 31,250 and 46,875 plants ha $\mathrm{hac}^{-1}$ accumulate nutrients in the following order: $\mathrm{Ca}>$ $\mathrm{N}>\mathrm{K}>\mathrm{Mg}>\mathrm{P}>\mathrm{S}$. Half of the total nutrients accumulated by cabbage plants is reached between 40 and 60 days after transplantation. The amounts of accumulated nutrients by cabbage plants are significantly influenced by soil fertilization and plant population.

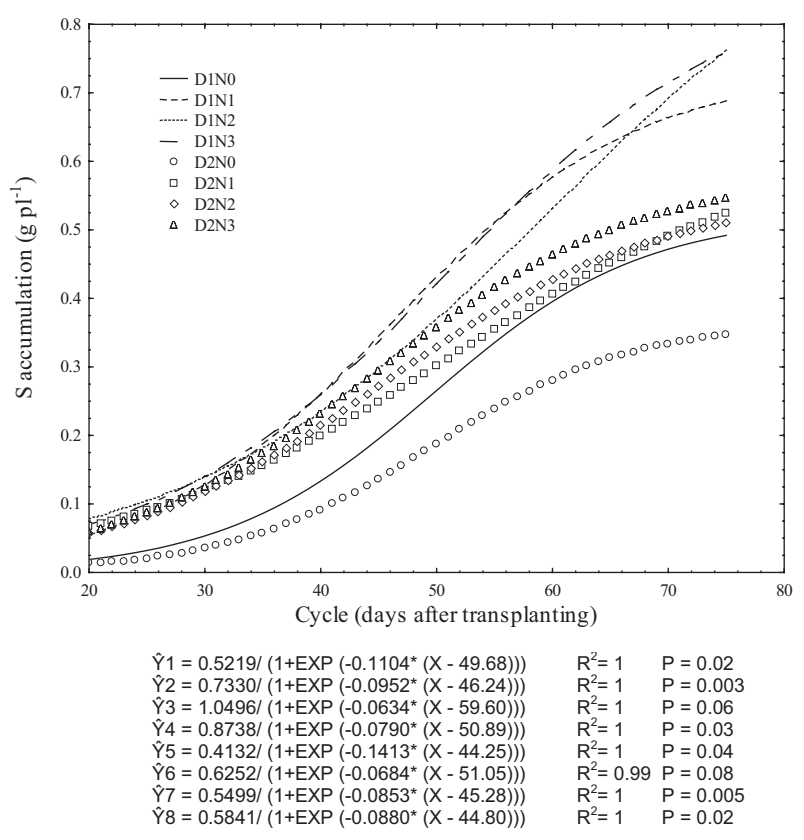

Figure 6. Sulfur accumulation during the plant cycle in the dry matter of the aerial part of cabbage plants of the 'Astrus' variety, as influenced by the doses of $0\left(\mathrm{~N}_{0}\right), 100\left(\mathrm{~N}_{1}\right), 200\left(\mathrm{~N}_{2}\right)$, and $300\left(\mathrm{~N}_{3}\right) \mathrm{kg} \mathrm{ha}^{-1}$ of $\mathrm{N}$ and the populations of $31,250\left(D_{1}\right)$ and 46,875 plants ha ${ }^{-1}\left(D_{2}\right)$. 


\title{
Resumen
}

\begin{abstract}
A.B. Cecílio Filho, R.L. Cavarianni y R.H.D. Nowaki. 2016. Influencia de la dosis de nitrógeno y la población de col 'Astrus', en la acumulación de macronutrientes en las plantas. Cien. Inv. Agr. 43(2):305-315. Con el fin de evaluar las interacciones entre las densidades de población (31250 y 46875 plantas ha $^{-1}$ ) y el nitrógeno $(0,100,200$ y $300 \mathrm{~kg}$ $\mathrm{ha}^{-1}$ ) en la acumulación de macronutrientes en la col cv. 'Astrus', se realizó un experimento en Jaboticabal (Brasil) del 18 de febrero al 2 de junio de 2004. El diseño experimental fue de bloques al azar factorial $2 \times 4$ con tres repeticiones. Se observó diferencia en la cantidad de macronutrientes de la col en función de $\mathrm{N}$ y la densidad de población. Se observaron las mayores cantidades al final del ciclo con la menor densidad de la siembra, pero las cantidades de N, P, K y S no fueron diferentes cuando se utilizan de 100 a $300 \mathrm{~kg} \mathrm{ha}^{-1}$ de N. Para Ca y Mg, las cantidades no fueron diferentes cuando se fertilizó con 200 o $300 \mathrm{~kg} \mathrm{ha}^{-1} \mathrm{de} \mathrm{N}$. La secuencia descendente de extracción de macronutrientes $(\mathrm{Ca}, \mathrm{N}, \mathrm{K}, \mathrm{Mg}, \mathrm{P}$ y S) no se vio afectada por los tratamientos. El período de 40 a 60 días después del trasplante fue responsable de la mitad de las cantidades acumuladas de macronutrientes en planta de la col.
\end{abstract}

Palabras clave: Brassica oleracea var. capitata, nutrientes de absorción, espaciamiento.

\section{References}

Aquino, L.A., M. Puiatti, P.R.G. Pereira, F.H.F. Pereira, M.R.S. Castro, and I.R. Ladeira. 2005a. Características produtivas do repolho em função de espaçamentos e doses de nitrogênio. Horticultura Brasileira 23:266-270.

Aquino, L.A., M. Puiatti, P.R.G. Pereira, F.H.F. Pereira, I.R. Ladeira, and M.R.S. Castro. 2005b. Efeito de espaçamentos e doses de nitrogênio sobre as características qualitativas da produção do repolho. Horticultura Brasileira 23:100-104.

Aquino, L.A., M. Puatti, M.M. Lelis, P.R.G. Pereira, and F.H.F. Pereira. 2009. Produção de Biomassa, Teor e Exportação de Macronutrientes em Plantas de Repolho em Função de Doses de Nitrogênio e de Espaçamentos. Ciência e Agrotecnologia (UFLA) 33:1295-1300.

Araújo, A.P., and C.T.T. Machado. 2006. Caracteres radiculares associados à absorção de fósforo. In: Fernandes M.S. (ed.). Nutrição Mineral de plantas. Viçosa, UFV, Brasil. p. 257-270.

Cecílio Filho, A.B., G.S. Silva, and J.W.M, Cortez. 2013. Phosphorus fertilization of 'Fuyutoyo' cabbages in phosphorus-rich Eutrustox soil. Chilean Journal of Agricultural Research 73:288-292.
Ekbladh, G., E. Witter, and T. Ericsson. 2007. Ontogenetic decline in the nitrogen concentration of field grown white cabbage- Relation to growth components. Scientia Horticulturae 112:149155.

Furlani, A.M.C., P.R. Furlani, and O.C. Bataglia. 1978. Composição mineral de diversas hortaliças. Bragantia 37:33-44.

Haque, K.M.F., A.A. Jahangir, M.E. Haque, R.K. Mondal, M.A.A. Jahanb, and M.A.M. Sarker. 2006. Yield and Nutritional Quality of Cabbage as Affected by Nitrogen and Phosphorus Fertilization Bangladesh J. Sci. Ind. Res. 41(1-2):4146.

Hawkesford, M., W. Horst, T. Kichey, H. Lambers, J. Schjoerring, I. Skrumsager Moller, and P. White. 2012. Function of macronutrients. In: Marschner, P. (ed.). Marschner'smineral Nutrition. 3 ed. Oxford, UK: ElSevier Ltd. p. 135-178.

Khan, R., S. Ahmed, S. Khan, F. Ahmed, M. Zaman, and B.A. Khan. 2002. Effect of different levels of nitrogen, phosphorus and potassium on the growth and yield of cabbage. Asian Journal of Plant Sciences 1:548-549.

Kolota, E., and P. Chohura. 2015. Control of head size and nutritional value of cabbage by plant 
population and nitrogen fertilization. Acta Scientiarum Polonorum Hortorum Cultus 14:75-85.

Machado, J.R., V. Mendonça, M.S. Tosta, G.A. Biscaro, A.C. Silva, and J.S. Tosta. 2006. Adubação nitrogenada em cobertura na produção de repolho nas condições de Cassilândia-MS. Available online at: http://www.abhorticultura.com.br/biblioteca/arquivos/Download/Biblioteca/46_0478. pdf (Website accessed: September 20, 2013).

Moreira, M.A., S.M. Vidigal, M.A.N. Sediyama, and M.R. Santos. 2011. Crescimento e produção de repolho em função de doses de nitrogênio. Horticultura Brasileira 29:117-121.

Oktem, A., A.G. Oktem, and H.Y. Emeklier. 2010. Effect of nitrogen on yield and some quality parameters of sweet corn. Communications in Soil Science and Plant Analysis 41:832-847.

Oliveira, F.L., R.G.T. Ribas, R.M. Junqueira, M.P. Padovan, J.G.M. Guerra, D.L. Almeida, and R.L.D. Ribeiro. 2003. Uso do pré-cultivo de Crotalaria juncea e de doses crescentes de "cama" de aviário na produção do repolho sob manejo orgânico. Agronomia, Rio de Janeiro 37:60-66.

Peck, N.H. 1981. Cabbage plant responses to nitrogen fertilization. Agronomy Journal 73:679-784.

Raij, B., J.A. Quaggio, H. Cantarella, and C.A. Abreu. 1997. Interpretação de resultados de análise de solo. In: Raij, B., H. Cantarella, J.A. Quaggio, and A.M.C. Furlani (eds.). Recomendações de adubação e calagem para o estado de São Paulo. Campinas, Brasil. Boletim Técnico 100. 285 pp.
Sady, W., R. Wojciechowska, and S. Rozek. 2001. The effect of form and placement of $\mathrm{N}$ on yield and nitrate content of white cabbage. Acta Horticulture 563:123-128.

Schellenberg, D.L., A.D. Bratsch, and Z. Shen. 2009. Large Single-head Broccoli Yield as affected by plant density, nitrogen, and cultivar in a plasticulture system HortTechnology 19:792-795.

Silva, F.C. 2009. Manual de análises químicas de solos, plantas e fertilizantes. EMBRAPA. Brasília, Brasil. 627 pp.

Trani, P.E., F.A. Passos, J.A. Azevedo, and M. Tavares. 1997. Brócolos, couve-flor e repolho. In: Raij, B., H. Cantarella, J.A. Quaggio, A.M.C. Furlani. (eds.). Recomendações de adubação e calagem para o Estado de São Paulo. Campinas, Brasil. Boletim Técnico 100. p. 175-179.

Westerveld, S.M., A.W. McKeown, and C.D. ScottDupree. 2004. Assessment of chlorophyll and meters as field tissue nitrogen test for cabbage, onions and carrots. HortTechnology 14:179188.

Westerveld, S.M., M.R. McDonald, C.D. ScottDupree, and A.W. McKeown. 2003a. Optimum nitrogen fertilization of summer cabbage in Ontario. Acta Horticulturae 627:211-215.

Westerveld, S.M., A.W. McKeown, C.D. ScottDupree, and M.R. McDonald. 2003b. How well do critical nitrogen concentrations work for cabbage, carrot, and onion crops? HortScience 38:1122-1128. 
